\title{
Toxicology of solvent extract and fractions of Alstonia boonei (DC.) Wild stem bark in Rats
}

\author{
Oludele John Olanlokun*, Olufunso Olabode Olorunsogo \\ Laboratories for Biomembrane Research and Biotechnology, Department of Biochemistry, Faculty of Basic Medical Sciences, College of Medicine, \\ University of Ibadan
}

\section{A R T I C L E I N F O}

Article Type:

Original Article

\section{Article History:}

Received: 9 November 2017

Accepted: 7 April 2018

\section{Keywords:}

Hematological parameters

Marker enzymes

Hepatotoxicity

Nephrotoxicity

Recovery

\begin{abstract}
A B S T R A C T
Introduction: Toxic effects arising from the use of medicinal herbs have been frequently overshadowed by the therapeutic efficacy of phytomedicines. This study was carried out to assess the safety of extract and fractions of Alstonia boonei (de wild) stem bark, popularly used in the treatment of malaria especially in Africa.

Methods: Rats were orally exposed to different doses (200 and $400 \mathrm{mg} / \mathrm{kg}$ body weight) of methanol extract (ME), $n$-hexane (HF), chloroform (CF), ethylacetate (EF) and aqueous fractions (AF) of A. boonei for 7 days. Furthermore, $10 \mathrm{mg} / \mathrm{kg}$ body weight (bw) of chloroquine (CQN) was administered as standard drug for 7 days while, $5 \%$ tween 80 (TT) and distilled water (TW) were administered as control for 7 days. Group I (treatment group) was sacrificed after 7 days while group II (recovery group) was left for 21 days to recover and thereafter sacrificed. The effects of treatment and recovery were analyzed using serum biomarkers, hematological parameters and tissue histopathological evaluation.

Results: There was reduction in hematological parameters after 7 days but recovered after 21 days. There was also increase in serum alanine aminotransferase (ALT), aspartate aminotransferase (AST) and alkaline phosphatase (ALP), after 7 days. Compared to TW and TT treated groups, histopathological scores of liver and kidney were critical for all groups at 400 $\mathrm{mg} / \mathrm{kg}$ bw after 21 days.

Conclusion: The animals did not fully recover after 21 days, suggesting that $400 \mathrm{mg} / \mathrm{kg}$ bw of extract and fractions of $A$. boonei were both hepatotoxic and nephrotoxic. Hence this plant should be used with caution.
\end{abstract}

\section{Implication for health policy/practice/research/medical education:}

The extract and fractions of $A$. boonei are not only toxic, but also recovery from the toxic effects is also not within a short-term limit. Hence, in general the safety of herbs must be considered when using them for therapeutic and prophylactic purposes.

Please cite this paper as: Olanlokun JO, Olorunsogo OO. Toxicology of solvent extract and fractions of Alstonia boonei (DC.) Wild stem bark in Rats. J Herbmed Pharmacol. 2018;7(3):129-135. doi: 10.15171/jhp.2018.22.

\section{Introduction}

Plants are cheap sources of medicinal intervention both for curative and preventive measures. In African and Asian continents, a greater percentage of the entire population relies solely on phytomedicine because of their folkloric and high efficiency. Herbs are prepared as infusion of a mixture of plants, a whole plant or plant parts containing phytochemical components some of which may not be necessary for the reasons why the decoction was prepared. Alstonia boonei (de wild), a deciduous plant of the Apocynaceae family is well known for its antimalarial activity and other therapeutic efficacies. The folkloric use of this plant for therapeutic and prophylactic antimalarial purposes has been justified with scientific research $(1,2)$. A herbal medicine may be taken in a toxic dose because of self-treatment (3), management and preparation of the phytomedicine by unqualified practitioners (4), substandard phytomedical products and the presence of heavy metals and toxins in the herbal decoctions (5) and/ or improper intake (6). Herbal drugs may be nephrotoxic (7), hepatotoxic (8), cardiotoxic (9) or neurotoxic (10). It has been reported that Africans that are vulnerable to kidney diseases are mostly those that rely on traditional medicines and that herbal medicines account for about 
30\%-35\% of acute kidney diseases in Africa (11). Because of its central role in metabolizing herbs and herbal products ingested, the liver is one of the internal organs affected directly by herbs or indirectly by their metabolites (12). While some common plants used as herbal medicines have shown clinical signs of cardiotoxicity due to their adverse effects on some cardiac events such as blood pressure and inflammation of myocardium, some have neurotoxic effects $(10,13)$. Few researches have been done to assess the toxicity of $A$. boonei. The ethanol extract of A. boonei stem bark might be toxic when co-administered with DDVP (2, 2-dichlorovinyl dimethyl phosphate) (14). However, there is paucity of information on the duration of recovery from the toxic effects of administration of various solvent fractions of the stem bark extract or if a permanent damage is to be established as a result of the toxicity of this plant. Besides, the doses of extract and fractions of $A$. boonei used in this work and duration have been used in antimalarial works $(1,2)$ and so it is a representative of expected toxicity of such experimental design. It is against this background that we assessed the toxic effects of oral administration of extracts and fractions of $A$. boonei and levels of recovery after 21 days of drug withdrawal.

\section{Materials and Methods}

Chemicals

Methanol, $n$-hexane, chloroform and ethylacetate were obtained from Sigma-Aldrich chemicals, St. Louis MO, USA; chloroquine phosphate was obtained from Jopan Pharmaceuticals Nig. Ltd, Ajao Estate, Lagos Nigeria; Alnine and aspartate aminotransferases assay kits were obtained from Randox laboratories ltd. (Antrim, UK). All other chemicals used were of analytical grade and were obtained from British Drug Houses (Poole, Dorset, UK).

\section{Plant material}

Stem bark peels of $A$. boonei were obtained from Ekiti State University, Nigeria and were identified by $\mathrm{Mr}$. Omotayo, F.O. of the University Herbarium, Ekiti State University and a voucher number (UHAE013) was assigned to the sample. The peels were washed and airdried in the laboratory for 3 weeks after which they were pulverized, and soaked in methanol for 3 days. The filtrate was concentrated using rotary evaporator (Stuart, UK) to yield a dark brown methanol extract (ME).

\section{Partitioning of the methanol extract}

Methanol extract $(50 \mathrm{~g})$ was mixed with $250 \mathrm{~mL}$ of distilled water and partitioned successively between $n$-hexane, chloroform and ethylacetate to yield hexane $(\mathrm{HF})$, chloroform (CF), ethylacetate (EF) and aqueous fractions (AF) using a separating funnel. These were concentrated using rotary evaporator and were further concentrated in water bath at $40^{\circ} \mathrm{C}$ until constant weights were obtained. In this way, the solvents were removed and the dry fractions were stored in the refrigerator until used.
Animals

Seventy male rats (100-120 g) were obtained from the Central Animal House, College of Medicine, University of Ibadan, Nigeria and were broadly divided into two groups of thirty-five animals each for the acute and recovery experiments. Each fraction, extract, chloroquine and untreated control group had five animals each. Similar animal groupings were used for the recovery experiment. The animals were housed in clean cages and had access to clean water and standard rat pellets (Ladokun Feeds, Nigeria) ad libitum.

Animal treatment and sample collection The animals were exposed to 200 and $400 \mathrm{mg} / \mathrm{kg}$ bw doses of ME, HF, CF, EF AF and $10 \mathrm{mg} / \mathrm{kg}$ bw of chloroquine (CQN) orally, once daily for 7 days. The untreated control group received the vehicle -- water (TW) and 5\% v/v tween 80 (TT) for those days. After 7 days, the acute treated groups were sacrificed via cervical dislocation, opened up and blood was collected from the heart into plain sample bottles, spun at $3000 \mathrm{rpm}$ for 5 minutes and the serum was collected into another plain bottle. The recovery groups were left for 21 days without treatment and sacrificed after an overnight fast. Liver and kidney sections used for histopathology were excised and fixed in ten percent formalin until used.

Biochemical assays

Serum alanine, aspartate aminotransferases (ALT and AST) and alkaline phosphatase (ALP) were analyzed using Randox kits.

Hematological parameters

Packed cell volume (PCV), hemoglobin (Hb), total white blood cell count (TWBC), neutrophils (N), and lymphocytes (L) were estimated according to a previously defined method (15).

Tissue histopathology

The fixed liver and kidney tissues were dehydrated by ascending grades of isopropyl alcohol for an hour. The dehydrated organs were cleared in xylene and transferred into two changes of liquid paraffin wax. The tissue sections were stained in Ehrlich's hematoxylin for 8 minutes, washed in water and dipped in acid alcohol to remove excess stain. These were counter stained in $10 \%$ aqueous eosin, incubated and mounted for photomicrography.

\section{Statistical analysis}

All values were expressed as mean \pm standard deviation (SD). Data were analyzed using Duncan's multiple range test and level of significance was set at $P<0.05$.

\section{Results}

Tables 1 and 2 respectively show the effects of oral administration of $200 \mathrm{mg} / \mathrm{kg}$ bw of the extract and 
Table 1. Hematological effects of $200 \mathrm{mg} / \mathrm{kg}$ bw of extract and fractions of Alstonia boonei in rats after 7 days

\begin{tabular}{|c|c|c|c|c|c|}
\hline Drugs & PCV (\%) & TWBC (cumm ${ }^{-1}$ ) & $\mathrm{Hb}(\mathrm{g} / \mathrm{dL})$ & N (\%) & L (\%) \\
\hline ME & $38.50^{\mathrm{a}} \pm 4.93$ & $5975.00^{\mathrm{a}} \pm 1078.19$ & $12.65^{\mathrm{a}} \pm 1.70$ & $14.75^{\mathrm{ab}} \pm 6.07$ & $85.00^{\mathrm{a}} \pm 6.37$ \\
\hline $\mathrm{HF}$ & $36.00^{\mathrm{a}} \pm 4.24$ & $5350.00^{\mathrm{a}} \pm 1799.07$ & $11.97^{\mathrm{a}} \pm 1.39$ & $26.00^{\mathrm{ab}} \pm 9.34$ & $73.50^{a} \pm 9.03$ \\
\hline $\mathrm{CF}$ & $34.25^{\mathrm{a}} \pm 4.34$ & $4500.00^{a} \pm 1000.00$ & $11.35^{\mathrm{a}} \pm 1.39$ & $30.75^{b} \pm 14.17$ & $71.25^{\mathrm{a}} \pm 12.09$ \\
\hline EF & $35.50^{\mathrm{a}} \pm 4.04$ & $6750.00^{\mathrm{b}} \pm 613.73$ & $11.80^{\mathrm{a}} \pm 1.33$ & $23.25^{\mathrm{ab}} \pm 9.21$ & $76.00^{a} \pm 9.20$ \\
\hline $\mathrm{AF}$ & $37.00^{\mathrm{a}} \pm 4.08$ & $5600.00^{\mathrm{a}} \pm 1564.18$ & $12.05^{\mathrm{a}} \pm 1.02$ & $12.75^{\mathrm{ab}} \pm 2.42$ & $87.25^{\mathrm{a} \pm 12.41}$ \\
\hline TW & $40.00^{\mathrm{b}} \pm 8.49$ & $6500.00^{\mathrm{b}} \pm 282.84$ & $13.30^{\mathrm{a}} \pm 1.61$ & $14.50^{\mathrm{ab}} \pm 6.36$ & $89.50^{a} \pm 15.90$ \\
\hline CQN & $34.25^{a} \pm 8.96$ & $4600.00^{a} \pm 743.86$ & $12.03^{\mathrm{a}} \pm 1.61$ & $11.50^{\mathrm{a}} \pm 3.79$ & $88.50^{\mathrm{a}} \pm 4.03$ \\
\hline TT & $37.50^{\mathrm{a}} \pm 2.65$ & $4725.00^{\mathrm{a}} \pm 1791.42$ & $12.42^{\mathrm{a}} \pm 0.89$ & $20.25^{\mathrm{ab}} \pm 5.35$ & $78.75^{a} \pm 6.36$ \\
\hline
\end{tabular}

Methanol extract (ME); n-Hexane fraction (HF); Chloroform fraction (CF); Ethylacetate fraction (EF); Aqueous fraction (AF); Treated with water only (TW); Chloroquine (CQN); Tween 80 (5\% v/v) only (TT); Packed cell volume (PCV); Total white blood cell (TWBC); Hemoglobin (Hb); Neutrophil (N); Lymphocyte (L). Values are mean of five determinations \pm standard deviation. Values with different superscripts within the column are significantly different at $P<0.05$.

Table 2. Hematological effects of $200 \mathrm{mg} / \mathrm{kg}$ bw of extract and fractions of Alstonia boonei in rats after 21 days

\begin{tabular}{|c|c|c|c|c|c|}
\hline Drugs & PCV (\%) & TWBC (cumm ${ }^{-1}$ ) & $\mathrm{Hb}(\mathrm{g} / \mathrm{dL})$ & N (\%) & L (\%) \\
\hline ME & $41.25^{b} \pm 2.63$ & $6675.00^{\mathrm{a}} \pm 665.21$ & $13.73^{b} \pm 0.8$ & $5.50^{b} \pm 2.38$ & $90.25^{a} \pm 2.62$ \\
\hline $\mathrm{HF}$ & $33.50^{\mathrm{a}} \pm 7.3$ & $7675.00^{b} \pm 607.59$ & $11.13^{\mathrm{b}} \pm 2.41$ & $13.25^{\mathrm{a}} \pm 11.35$ & $86.00^{\mathrm{a}} \pm 12.11$ \\
\hline $\mathrm{CF}$ & $38.00^{\mathrm{b}} \pm 0.81$ & $6775.00^{\mathrm{ab}} \pm 2085.47$ & $12.63^{b} \pm 0.29$ & $8.50^{\mathrm{b}} \pm 8.06$ & $91.50^{a} \pm 8.06$ \\
\hline EF & $41.75^{b} \pm 0.96$ & $8075.00^{\mathrm{b}} \pm 991.21$ & $13.88^{\mathrm{b}} \pm 0.34$ & $12.50^{\mathrm{a}} \pm 3.87$ & $87.50^{\mathrm{a}} \pm 3.87$ \\
\hline AF & $34.00^{\mathrm{a}} \pm 6.38$ & $6650.00^{\mathrm{ab}} \pm 2389.56$ & $11.30^{\mathrm{b}} \pm 0.34$ & $15.75^{\mathrm{a}} \pm 4.92$ & $84.00^{a} \pm 5.23$ \\
\hline TW & $46.00^{b} \pm 0.00$ & $6700.00^{\mathrm{ab}} \pm 0.00$ & $15.60^{a} \pm 0.00$ & $7.00^{b} \pm 0.00$ & $93.50^{a} \pm 0.00$ \\
\hline CQN & $40.00^{b} \pm 4.32$ & $4675.00^{a} \pm 1379.31$ & $13.30^{\mathrm{b}} \pm 1.44$ & $6.25^{a} \pm 5.18$ & $93.00^{a} \pm 5.68$ \\
\hline TT & $37.00^{b} \pm 6.27$ & $7400.00^{\mathrm{b}} \pm 1557.78$ & $12.30^{\mathrm{b}} \pm 2.12$ & $10.00^{\mathrm{a}} \pm 5.29$ & $91.00^{a} \pm 6.06$ \\
\hline
\end{tabular}

Methanol extract (ME); n-Hexane fraction (HF); Chloroform fraction (CF); Ethylacetate fraction (EF); Aqueous fraction (AF); Treated with water only (TW); Chloroquine (CQN); Tween 80 (5\% v/v) only (TT); Packed cell volume (PCV); Total white blood cell (TWBC); Hemoglobin (Hb); Neutrophil (N); Lymphocyte (L). Values are mean of five determinations \pm standard deviation. Values with different superscripts within the column are significantly different at $P<0.05$.

fractions of the methanol stem bark extract of $A$. boonei on blood parameters. The PCV, TWBC, $\mathrm{Hb}$ and $\mathrm{L}$ values increased albeit insignificantly after a recovery period of 21 days among groups administered with ME, HF, CF, EF and CQN while there was no significant difference when values of the hematological parameters were compared among the extract and fractions. In all these parameters, animals treated with water (TW) had the highest values both after 7 days treatment and 21 days recovery except in TWBC.

Tables 3 and 4 respectively show the effects of the extract and fractions of the methanol stem bark extract of $A$. boonei on some hematological parameters at $400 \mathrm{mg} /$ kg bw dose after 7 days treatment and 21 days recovery period. The results obtained showed a similar trend with $200 \mathrm{mg} / \mathrm{kg}$ bw dose but with severe and critical effects. Biochemical studies on AST, ALT and ALP activities (Tables 5, 6, 7 and 8) at 200 and $400 \mathrm{mg} / \mathrm{kg}$ bw dose of A. boonei extract and fractions showed that the enzyme activities increased dose dependently with maximal effect noticed in the CF group. There was no significant decrease in the activities of these enzymes after 21 days.

Histopathological studies (Figure 1) revealed the lesions both in the liver and kidney of animals treated with 400

Table 3. Hematological effects of $400 \mathrm{mg} / \mathrm{kg}$ bw of extract and fractions of Alstonia boonei in rats after 7 days

\begin{tabular}{|c|c|c|c|c|c|}
\hline Drugs & PCV (\%) & TWBC (cumm ${ }^{-1}$ ) & $\mathrm{Hb}(\mathrm{g} / \mathrm{dL})$ & $\mathrm{N}(\%)$ & L (\%) \\
\hline ME & $39.00^{\mathrm{a}} \pm 2.82$ & $5325.00^{\mathrm{a}} \pm 1650$ & $12.95^{\mathrm{a}} \pm 0.96$ & $24.73^{\mathrm{a}} \pm 3.40$ & $74.25^{\mathrm{a}} \pm 3.30$ \\
\hline HF & $38.50^{\mathrm{a}} \pm 4.12$ & $6200.00^{\mathrm{a}} \pm 983.19$ & $12.82^{\mathrm{a}} \pm 1.36$ & $17.50^{\mathrm{a}} \pm 1.63$ & $74.75^{\mathrm{a}} \pm 4.73$ \\
\hline $\mathrm{CF}$ & $32.25^{\mathrm{a}} \pm 4.03$ & $5900.00^{\mathrm{a}} \pm 2824.89$ & $10.72^{\mathrm{a}} \pm 1.33$ & $13.50^{\mathrm{a}} \pm 1.18$ & $85.75^{a} \pm 5.11$ \\
\hline EF & $31.50^{\mathrm{a}} \pm 5.80$ & $5925.00^{a} \pm 1740.45$ & $10.42^{\mathrm{a}} \pm 1.99$ & $26.25^{\mathrm{ab}} \pm 1.90$ & $72.75^{a} \pm 10.53$ \\
\hline AF & $34.00^{\mathrm{a}} \pm 1.41$ & $4950.00^{\mathrm{a}} \pm 1791.42$ & $11.32^{\mathrm{a}} \pm 0.47$ & $27.75^{\mathrm{a}} \pm 1.08$ & $71.50^{a} \pm 9.77$ \\
\hline TW & $40.00^{\mathrm{b}} \pm 8.49$ & $6500.00^{\mathrm{b}} \pm 282.84$ & $13.30^{\mathrm{a}} \pm 1.61$ & $14.50^{\mathrm{ab}} \pm 6.36$ & $89.50^{\mathrm{a}} \pm 15.90$ \\
\hline CQN & $34.25^{a} \pm 8.96$ & $4600.00^{\mathrm{a}} \pm 743.86$ & $12.03^{\mathrm{a}} \pm 1.61$ & $11.50^{\mathrm{a}} \pm 3.79$ & $88.50^{a} \pm 4.03$ \\
\hline TT & $37.50^{\mathrm{a}} \pm 2.65$ & $4725.00^{\mathrm{a}} \pm 1791.42$ & $12.42^{\mathrm{a}} \pm 0.89$ & $20.25^{\mathrm{ab}} \pm 5.35$ & $78.75^{a} \pm 6.36$ \\
\hline
\end{tabular}

Methanol extract (ME); n-Hexane fraction (HF); Chloroform fraction (CF); Ethylacetate fraction (EF); Aqueous fraction (AF); Treated with water only (TW); Chloroquine (CQN); Tween 80 (5\% v/v) only (TT); Packed cell volume (PCV); Total white blood cell (TWBC); Hemoglobin (Hb); Neutrophil (N); Lymphocyte (L). Values are mean of five determinations \pm standard deviation. Values with different superscripts within the column are significantly different at $P<0.05$. 
Table 4. Hematological effects of $400 \mathrm{mg} / \mathrm{kg}$ bw of extract and fractions of Alstonia boonei in rats after 21 days

\begin{tabular}{|c|c|c|c|c|c|}
\hline Drugs & PCV (\%) & TWBC (cumm ${ }^{-1}$ ) & $\mathrm{Hb}(\mathrm{g} / \mathrm{dL})$ & $N(\%)$ & L (\%) \\
\hline $\mathrm{ME}$ & $42.333^{a} \pm 1.52$ & $5633.33^{a} \pm 981.49$ & $14.06^{b} \pm 0.50$ & $10.67^{a} \pm 2.08$ & $88.69^{a} \pm 3.21$ \\
\hline $\mathrm{HF}$ & $39.25^{b} \pm 2.22$ & $7625.00^{\mathrm{ab}} \pm 1102.65$ & $13.05^{b} \pm 0.71$ & $8.75^{a} \pm 6.80$ & $91.00^{\mathrm{a}} \pm 7.25$ \\
\hline CF & $41.00^{\mathrm{a}} \pm 1.41$ & $9200.00^{b} \pm 1414.21$ & $13.65^{b} \pm 0.49$ & $19.00^{\mathrm{a}} \pm 2.21$ & $80.50^{a} \pm 21.92$ \\
\hline EF & $39.00^{b} \pm 1.83$ & $5900.00^{\mathrm{a}} \pm 2426.25$ & $12.95^{b} \pm 0.34$ & $17.25^{\mathrm{a}} \pm 14.89$ & $82.50^{\mathrm{a}} \pm 14.02$ \\
\hline $\mathrm{AF}$ & $37.33^{b} \pm 2.31$ & $6666.67^{\mathrm{ab}} \pm 1553.49$ & $12.43^{b} \pm 0.75$ & $11.00^{\mathrm{a}} \pm 2.00$ & $89.00^{a} \pm 2.02$ \\
\hline TW & $46.00^{\mathrm{b}} \pm 0.00$ & $6700.00^{\mathrm{ab}} \pm 0.00$ & $15.60^{a} \pm 0.00$ & $7.00^{\mathrm{b}} \pm 0.00$ & $93.50^{\mathrm{a}} \pm 0.00$ \\
\hline CQN & $40.00^{b} \pm 4.32$ & $4675.00^{\mathrm{a}} \pm 1379.31$ & $13.30^{\mathrm{b}} \pm 1.44$ & $6.25^{\mathrm{a}} \pm 5.18$ & $93.00^{a} \pm 5.68$ \\
\hline TT & $37.00^{b} \pm 6.27$ & $7400.00^{b} \pm 1557.78$ & $12.30^{\mathrm{b}} \pm 2.12$ & $10.00^{\mathrm{a}} \pm 5.29$ & $91.00^{\mathrm{a}} \pm 6.06$ \\
\hline
\end{tabular}

Methanol extract (ME); $n$-Hexane fraction (HF); Chloroform fraction (CF); Ethylacetate fraction (EF); Aqueous fraction (AF); Treated with water only (TW); Chloroquine (CQN); Tween 80 (5\% v/v) only (TT); Packed cell volume (PCV); Total white blood cell (TWBC); Hemoglobin (Hb); Neutrophil (N); Lymphocyte (L). Values are mean of five determinations \pm standard deviation. Values with different superscripts within the column are significantly different at $P<0.05$.

$\mathrm{mg} / \mathrm{kg}$ bw of the drug candidates after 21 days. The results obtained showed that there was portal congestion (ME), diffuse vacuolar degeneration (HF, EF CQN and AF), and severe diffuse hepatic vacuolation with central venous

Table 5. Effects of $200 \mathrm{mg} / \mathrm{kg}$ bw of extract and fractions of Alstonia booneion AST, ALT and ALP after 7 days

\begin{tabular}{llll}
\hline Drugs & ALT (U/L) & AST (U/L) & ALP (U/L) \\
\hline ME & $120.70^{\mathrm{ab}} \pm 10.14$ & $57.20^{\mathrm{bcd}} \pm 2.47$ & $220.81^{\mathrm{a}} \pm 28.61$ \\
HF & $83.03^{\mathrm{a}} \pm 8.25$ & $33.72^{\mathrm{a}} \pm 2.09$ & $227.03^{\mathrm{ab}} \pm 20.49$ \\
CF & $126.83^{\mathrm{b}} \pm 8.34$ & $61.16^{\mathrm{cd}} \pm 9.82$ & $243.57^{\mathrm{ab}} \pm 20.49$ \\
EF & $115.20 \pm 6.25$ & $53.44^{\mathrm{abcd}} \pm 8.92$ & $200.19^{\mathrm{a}} \pm 44.46$ \\
AF & $110.78^{\mathrm{ab}} \pm 3.90$ & $48.20^{\mathrm{abc}} \pm 3.25$ & $222.18^{\mathrm{a}} \pm 6.11$ \\
TW & $46.25^{\mathrm{c}} \pm 3.18$ & $48.24^{\mathrm{abcd}} \pm 3.62$ & $75.90^{\mathrm{a}} \pm 0.74$ \\
CQN & $98.55^{\mathrm{ab}} \pm 2.73$ & $40.68^{\mathrm{abc}} \pm 3.98$ & $517.50^{\mathrm{a} b} \pm 13.21$ \\
TT & $40.95^{\mathrm{c}} \pm 7.33$ & $37.24^{\mathrm{ab}} \pm 8.82$ & $51.75^{\mathrm{a}} \pm 6.83$ \\
\hline
\end{tabular}

Methanol extract (ME); n-Hexane fraction (HF); Chloroform fraction (CF); Ethylacetate fraction (EF); Aqueous fraction (AF); Treated with water only (TW); Chloroquine (CQN); Tween 80 (5\% v/v) only (TT); Aspartate aminotransferase (AST); Alanine aminotransferase (ATL); alkaline phosphatase (ALP). Values are mean of five determinations \pm standard deviation. Values are mean of five determinations \pm standard deviation. Values with different superscripts within the column are significantly different at $P<0.05$.

Table 6. Effects of $200 \mathrm{mg} / \mathrm{kg}$ bw of extract and fractions of Alstonia booneion AST, ALT and ALP after 21 days

\begin{tabular}{llll}
\hline Drugs & ALT (U/L) & AST (U/L) & ALP (U/L) \\
\hline ME & $117.90^{\mathrm{ab}} \pm 7.14$ & $52.11^{\mathrm{ab}} \pm 22.00$ & $200.01^{\mathrm{a}} \pm 5.86$ \\
HF & $80.13^{\mathrm{a}} \pm 3.24$ & $33.00^{\mathrm{a}} \pm 6.90$ & $218.04^{\mathrm{a}} \pm 10.73$ \\
CF & $120.88^{\mathrm{c}} \pm 0.07$ & $60.42^{\mathrm{c}} \pm 7.90$ & $220.12^{\mathrm{b}} \pm 3.14$ \\
EF & $110.20^{\mathrm{c}} \pm 3.14$ & $49.09^{\mathrm{abc}} \pm 2.41$ & $190.14^{\mathrm{d}} \pm 0.00$ \\
AF & $106.90^{\mathrm{bc}} \pm 3.14$ & $47.00^{\mathrm{ab}} \pm 2.91$ & $215.11^{\mathrm{b}} \pm 3.20$ \\
TW & $44.21^{\mathrm{c}} \pm 0.00$ & $45.00^{\mathrm{ab}} \pm 0.00$ & $78.04^{\mathrm{a}} \pm 0.00$ \\
CQN & $96.41^{\mathrm{ab}} \pm 7.71$ & $32.01^{\mathrm{a}} \pm 7.81$ & $476.50^{\mathrm{c}} \pm 5.99$ \\
TT & $46.21^{\mathrm{a}} \pm 9.36$ & $36.11^{\mathrm{ab}} \pm 14.82$ & $53.44^{\mathrm{a}} \pm 2.93$ \\
\hline
\end{tabular}

Methanol extract (ME); n-Hexane fraction (HF); Chloroform fraction (CF); Ethylacetate fraction (EF); Aqueous fraction (AF); Treated with water only (TW); Chloroquine (CQN); Tween 80 (5\% v/v) only (TT); Aspartate aminotransferase (AST); Alanine aminotransferase (ATL); alkaline phosphatase (ALP). Values are mean of five determinations \pm standard deviation. Values are mean of five determinations \pm standard deviation. Values with different superscripts within the column are significantly different at $P<0.05$. congestion (CF) after 21 days. The kidney showed few tubules with protein cast (ME and $\mathrm{HF}$ ), and moderate renal cortical congestion (EF and $\mathrm{AF}$ ). The kidney section of the CF showed marked renal cortical congestion and hemorrhage.

\section{Discussion}

Malaria is a fatal parasitic infection especially in the tropical African and Asian continent and it is believed that it kills more than AIDS and the most vulnerable are children under the age of 5 years (16). Herbal remedy, which in most cases, is a combination of two or more plants is usually taken ad libitum for the treatment or prevention of malaria in Africa. This good intention but with fatal consequences has its deleterious effects in terms of toxicities. The results obtained showed that PCV, $\mathrm{Hb}$, and TWBC decreased after 7 days but slightly increased after 21 days. The significant decrease in PCV observed in the HF and AF groups showed that these fractions might contain phytochemicals capable of causing hemolytic anemia possibly via the destabilization of the erythrocyte membrane $(17,18)$. The observed significant decrease in

Table 7. Effects of $400 \mathrm{mg} / \mathrm{kg}$ bw of extract and fractions of Alstonia booneion AST, ALT and ALP after 7 days

\begin{tabular}{llll}
\hline Drugs & ALT (U/L) & AST (U/L) & ALP (U/L) \\
\hline ME & $127.95^{\mathrm{ab}} \pm 16.85$ & $58.84^{\mathrm{abc}} \pm 5.69$ & $302.82^{\mathrm{a}} \pm 9.73$ \\
HF & $121.35^{\mathrm{ab}} \pm 29.3$ & $52.92^{\mathrm{b}} \pm 13.06$ & $448.64^{\mathrm{abc} \pm 4.39}$ \\
CF & $130.13^{\mathrm{b}} \pm 9.36$ & $81.68^{\mathrm{abc}} \pm 10.41$ & $536.65^{\mathrm{bc}} \pm 1.99$ \\
EF & $123.23 \pm 6.07$ & $58.92^{\mathrm{b}} \pm 14.02$ & $250.65^{\mathrm{abc}} \pm 1.99$ \\
AF & $121.73^{\mathrm{abc}} \pm 4.28$ & $49.12^{\mathrm{ab}} \pm 7.16$ & $445.91^{\mathrm{a}} \pm 11.28$ \\
TW & $46.25^{\mathrm{c}} \pm 3.18$ & $48.24^{\mathrm{abcd}} \pm 3.62$ & $75.90^{\mathrm{a}} \pm 0.74$ \\
CQN & $98.55^{\mathrm{ab}} \pm 2.73$ & $40.68^{\mathrm{abc}} \pm 3.98$ & $517.50^{\mathrm{ab}} \pm 13.21$ \\
TT & $40.95^{\mathrm{c}} \pm 7.33$ & $37.24^{\mathrm{ab}} \pm 8.82$ & $51.75^{\mathrm{a}} \pm 6.83$ \\
\hline
\end{tabular}

Methanol extract (ME); $\mathrm{n}$-Hexane fraction (HF); Chloroform fraction (CF); Ethylacetate fraction (EF); Aqueous fraction (AF); Treated with water only (TW); Chloroquine (CQN); Tween 80 (5\% v/v) only (TT); Aspartate aminotransferase (AST); Alanine aminotransferase (ATL); alkaline phosphatase (ALP). Values are mean of five determinations \pm standard deviation. Values are mean of five determinations \pm standard deviation. Values with different superscripts within the column are significantly different at $P<0.05$. 
Table 8. Effects of $400 \mathrm{mg} / \mathrm{kg}$ bw of extract and fractions of Alstonia booneion AST, ALT and ALP after 21 days

\begin{tabular}{lccc}
\hline Drugs & ALT (U/L) & AST (U/L) & ALP (U/L) \\
\hline ME & $120.01^{\mathrm{abc}} \pm 11.34$ & $50.10^{\mathrm{c}} \pm 15.61$ & $200.49^{\mathrm{d}} \pm 10.03$ \\
HF & $100.01^{\mathrm{bc}} \pm 38.12$ & $39.40^{\mathrm{bc}} \pm 21.27$ & $341.42^{\mathrm{bc}} \pm 4.98$ \\
CF & $126.40^{\mathrm{ab}} \pm 30.33$ & $70.62^{\mathrm{c}} \pm 4.29$ & $490.04^{\mathrm{ab}} \pm 4.87$ \\
EF & $119.00^{\mathrm{c}} \pm 19.34$ & $47.48^{\mathrm{ab}} \pm 9.92$ & $200.41^{\mathrm{c}} \pm 9.75$ \\
AF & $115.90^{\mathrm{a}} \pm 43.05$ & $40.44^{\mathrm{ab}} \pm 21.48$ & $296.11^{\mathrm{b}} \pm 8.78$ \\
TW & $44.21^{\mathrm{c}} \pm 0.00$ & $45.00^{\mathrm{ab}} \pm 0.00$ & $78.04^{\mathrm{a}} \pm 0.00$ \\
CQN & $96.41^{\mathrm{ab}} \pm 7.71$ & $32.01^{\mathrm{a}} \pm 7.81$ & $476.50^{\mathrm{c}} \pm 5.99$ \\
TT & $46.21^{\mathrm{c}} \pm 9.36$ & $36.11^{\mathrm{ab}} \pm 14.82$ & $53.44^{\mathrm{a}} \pm 2.93$ \\
\hline
\end{tabular}

Methanol extract (ME); n-Hexane fraction (HF); Chloroform fraction (CF); Ethylacetate fraction (EF); Aqueous fraction (AF); Treated with water only (TW); Chloroquine (CQN); Tween 80 (5\% v/v) only (TT); Aspartate aminotransferase (AST); Alanine aminotransferase (ATL); alkaline phosphatase (ALP). Values are mean of five determinations \pm standard deviation. Values are mean of five determinations \pm standard deviation. Values with different superscripts within the column are significantly different at $P<0.05$.

$\mathrm{Hb}$ of the test groups compared with the animals treated with water (TW) showed that the extract and fractions interfered with oxygen carrying capacity of blood cells or that the administration of the drug candidates impaired erythropoiesis (19). The significant increase in TWBC levels after 21 days compared with its levels after 7 days could be as a result of phytochemicals eliciting immune response to chemicals or as a result of secondary infections (20).

The reduction in the levels of neutrophils after the withdrawal of the drug candidates indicated that the extract and fractions repressed neutrophil production or enhanced its destruction maybe to minimize cellular injury because in addition to their immune response, neutrophils are implicated in tissue damage (21). An increase in the lymphocyte values showed that the extract and fractions enhanced the proliferation. This showed that the extract and fractions of $A$. boonei had immunosuppressive effects on neutrophils and immunostimulatory on lymphocyte proliferation. Some herbal preparations have immunomodulatory effects like this (22). The hematological parameters did not fall below a threshold which could pose danger to the animals, however, an increase in these hematological parameters following the withdrawal of the drug candidates showed that oral administration of the extract and fractions had reducing effects on them. A basal level of AST and ALT is found in the plasma which may increase when there is damage to tissues such as liver, kidney and heart. Increase in the serum level of ALP indicates liver injury or hepatitis (23). The reference values for AST (0 to $40 \mathrm{U} / \mathrm{L}$ ) and ALT ( 0 to $45 \mathrm{IU} / \mathrm{L}$ ) in human (24) showed that all values obtained for these enzymes from all the drug candidates at both doses and at 7 and 21 days were significantly higher than normal and it was evidently clear that damage was done to the liver. The increase in the activities of these enzymes after 7 days is indicative of the toxic effects of the extract and fractions of the stem bark extract of $A$. boonei. Subsequent decrease in the serum activities of these enzymes after 21 days did not reveal complete recovery. Microscopic examination of the liver and kidney sections after the recovery period of 21 days showed various lesions such as vacuolar degeneration, portal cellular infiltration by mononuclear cells and severe, diffuse hepatic vacuolation with central venous congestion, diffuse hepatic vacuolation and severe portal congestion with cellular infiltration by mononuclear cells and mild
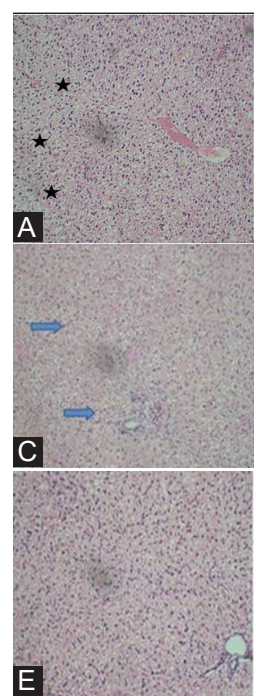

$\mathrm{E}$
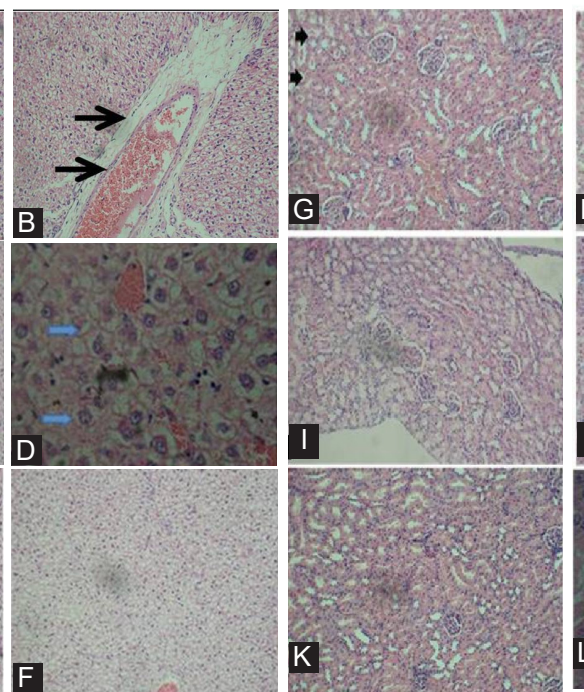

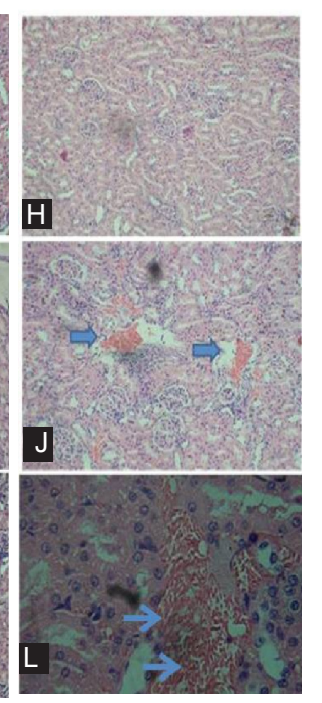

Figure 1. Histopathology of liver and kidney tissue sections of rats exposed to $400 \mathrm{mg} / \mathrm{kg}$ of $M E(A), \quad H F(B), E F(C), A F(D), C Q N(E)$ and CF (F) after 21 days of recovery. The result showed hepatic vacuolation ( black stars in A), severe portal congestion with cellular infiltration by mononuclear cells and mild fibroplasias (blue arrows in C and D). The kidney sections of the same treated groups (G-L respectively) showed renal cortical congestion and tubules with protein casts (black arrows in $\mathrm{G}$ ) and hemorrhage (blue arrows in $\mathrm{J}$ and $\mathrm{L}$ ). $\mathrm{ME}=$ Methanol Extract, $\mathrm{CQN}=$ Chloroquine, $\mathrm{HF}, \mathrm{CF}, \mathrm{EF}$ and $\mathrm{AF}$ are $n$-hexane, chloroform, ethylacetate and aqueous fractions respectively. 
fibroplasias, renal cortical congestion and hemorrhage. The congestion observed in the liver is evidence that the liver is involved in the biotransformation of xenobiotics. The kidney is an organ for excretion; therefore, it is exposed to both metabolized and un-metabolized toxicant for their removal from the body; the heavy task for the removal of toxicant from the body may cause much damage for the kidney. Again, some herbs may contain compounds such as oxalate which may chelate calcium and thus cause kidney stone. This means that high dose of extract and fractions of the methanol stem bark extract of $A$. boonei is both hepatotoxic and nephrotoxic and 21 days after the withdrawal of the drug did not give complete recovery. However, treatment of the negative control groups with water (TW) and 5\% v/v (TT) did not show any noticeable effects on the hematological parameters, marker enzymes and histological evaluation.

\section{Conclusion}

Taking together, the results obtained from this research work suggested a moderate intake of herbal formulation for the treatment of diseases because of the possible side effects. The extract and fractions of $A$. boonei are not only toxic, but also recovery from the toxic effects is not within a short-term limit. Although, administration of herbal medicines may be useful in the treatment of diseases, the secondary adverse effects must not be overlooked because in some cases, these side effects are more deleterious than the diseases these phytochemicals are originally used to treat. In conclusion, the safety of the administration of herbs must be considered when using them for therapeutic and prophylactic purposes.

\section{Authors' contribution}

OJO carried out the experiments and wrote the draft manuscript, OOO designed the experiment, supplied reagents and equipments and proofread the manuscript. All authors read and approved the manuscript.

\section{Conflict of interests}

The authors declared no conflict of interest.

\section{Ethical considerations}

All experimental procedures conform to the guiding principles for research as recommended by the Declaration of Helsinki and National Institute of Health.

\section{Funding/Support}

The authors were the financiers of this research project.

\section{Acknowledgements}

We acknowledge the priceless and invaluable efforts of Mr. Omotayo, F.O. of the University Herbarium, Ekiti State University, Nigeria who authenticated the samples used in this study. We also appreciate the efforts of Mr. Ogunsakin,
E.R., PhD student at Kwazulu Natal University, South Africa, for the statistical analysis.

\section{References}

1. Olanlokun JO, Bolaji OM, Agbedahunsi JM, Olorunsogo OO. Therapeutic effects of various solvent fractions of Alstonia boonei (apocynaceae) stem bark on Plasmodium berghei-induced malaria. Afr J Med Med Sci. 2012;41 Suppl:27-33.

2. Olanlokun JO, Bolaji OM, Agbedahunsi JM, Olorunsogo OO. Prophylactic potentials of extract of Alstonia boonei stem bark on chloroquine-sensitive $P$. berghei-induced malaria in mice. Arch Basic App Med. 2013;1:49-53.

3. Barrueto F, Tarabar A. Medscape. Herb Poisoning. http:// emedicine.medscape.com/article/817427-overview. Accessed December 2016.

4. Jennifer K. Medicine Management in Nursing Times, Toxicity and Adverse Effects of Herbal Complementary Therapy. https://www.nursingtimes.net/clinical-archive/ medicine-management/toxicity-and-adverse-effects-ofherbal-complementary-therapy/197707.article. 1 May 2002.

5. Barrett B, Kiefer D, Rabago D. Assessing the risks and benefits of herbal medicine: an overview of scientific evidence. Altern Ther Health Med. 1999;5(4):40-9.

6. Asif M. A brief study of toxic effects of some medicinal herbs on kidney. Adv Biomed Res. 2012;1:44. doi: 10.4103/22779175.100144.

7. Allard T, Wenner T, Greten HJ, Efferth T. Mechanisms of herb-induced nephrotoxicity. Curr Med Chem. 2013;20(22):2812-9.

8. Bunchorntavakul C, Reddy KR. Review article: herbal and dietary supplement hepatotoxicity. Aliment Pharmacol Ther. 2013;37(1):3-17. doi: 10.1111/apt.12109.

9. Andrade RJ, Robles M, Fernandez-Castaner A, LopezOrtega S, Lopez-Vega MC, Lucena MI. Assessment of druginduced hepatotoxicity in clinical practice: a challenge for gastroenterologists. World J Gastroenterol. 2007;13(3):32940.

10. Nielsen E, Brant J. Chemotherapy-induced neurotoxicity: assessment and interventions for patients at risk. Am J Nurs. 2002;102 Suppl 4:16-9; quiz 49-52.

11. Brown AC. Kidney toxicity related to herbs and dietary supplements: Online table of case reports. Part 3 of 5 series. Food Chem Toxicol. 2017;107(Pt A):502-19. doi: 10.1016/j. fct.2016.07.024.

12. Au JS, Navarro VJ, Rossi S. Review article: Drug-induced liver injury--its pathophysiology and evolving diagnostic tools. Aliment Pharmacol Ther. 2011;34(1):11-20. doi: 10.1111/j.1365-2036.2011.04674.x.

13. Pai VB, Nahata MC. Cardiotoxicity of chemotherapeutic agents: incidence, treatment and prevention. Drug Saf. 2000;22(4):263-302.

14. Ojo OA, Ajiboye B, Oyinloye BE, Akintayo CO. Prophylactic Effects of Ethanolic Extract of Alstonia boonei Stem Bark Against DDVP-induced Toxicity in Albino Rats. J Pharm Biomed Sci. 2014; 4(7): 650-657.

15. Jain NC. Schalm's Veterinary Hematology. 4th ed. Philadelphia, USA: Lea and Febiger; 1986. 
16. World Health Organization. World Malaria Report. Geneva: WHO; 2014.

17. Ileke KD, Odeyemi OO, Ashamo MO. Phytochemical Screening and Effectiveness of Alstonia boonei De Wild oils as an Entomocides in the Management of Cowpea bruchid, Callosobruchus maculatus (Fab.) [Coleoptera: Chrysomelidae]. International Journal of Horticulture. 2014;4(6):24-31.

18. Opoku F, Akoto O. Antimicrobial and phytochemical properties of Alstonia boonei extracts. Organic Chemistry: Current Research. 2015;4(1):137. doi: 10.4172/21610401.1000137.

19. Chattopadhyay RR. Possible mechanism of hepatoprotective activity of Azadirachta indica leaf extract: part II. J Ethnopharmacol. 2003;89(2-3):217-9.

20. Adebayo AH, Abolaji AO, Opata TK, Adegbenro IK.
Effects of ethanolic leaf extract of Chrysophyllum albidum G. on biochemical and haematological parameters of albino Wistar rats. Afr J Biotechnol. 2010;9(14):2145-50.

21. Kruger P, Saffarzadeh M, Weber AN, Rieber N, Radsak M, von Bernuth $\mathrm{H}$, et al. Neutrophils: Between host defence, immune modulation, and tissue injury. PLoS Pathog. 2015;11(3):e1004651. doi: 10.1371/journal.ppat.1004651.

22. Adebiyi OE, Abatan MO. Phytochemical and acute toxicity of ethanolic extract of Enantia chlorantha (oliv) stem bark in albino rats. Interdiscip Toxicol. 2013;6(3):145-51. doi: 10.2478/intox-2013-0023.

23. Gowda S, Desai PB, Hull VV, Math AA, Vernekar SN, Kulkarni SS. A review on laboratory liver function tests. Pan Afr Med J. 2009;3:17.

24. Melissa P. Guide of hepatitis and liver disease. Am J Biochem. 2004;13:234-6. 